\title{
Fejezetek az egyházi tanítóképzés magyarországi történetéből
}

\section{Mészáros László* és Szenczi Árpád **}

* Károli Gáspár Református Egyetem Tanítóképző Főiskolai Kar, főiskolai docens, e-mail: meszaros.laszlo@kre.hu

** Károli Gáspár Református Egyetem Tanítóképző Főiskolai Kar, főiskolai tanár, e-mail: szenczi.arpad@kre.hu

Az 1950-es évek végéig múködő középfokú egyházi tanitóképzők nevelési rendszerének történeti kutatását a Károli Gáspár Egyetem oktatói immár három évtizede tanulmányozzák. Akkori kutatás céljában a következőket fogalmazták meg: „Az újrainduló egyházi intézmények önálló müködéséhez elengedhetetlen feltétel a történelmi múlt feltárása, a hasonló profilú pedagógusképzők szellemiségének, nevelési rendszerének vizsgálata, az elméleti és gyakorlati képzésük összehasonlitása, a tanulságok felhasználása" (Szenczi, 1990). A kutatási eredmények értékelése során bebizonyosodott, hogy az egyházi tanitóképzés szellemisége rekonstruálható, mert van egy szintetizáló erő, amely az intézményeket a történelmi küldetésen felül is „életben tartotta”. Pauler Ákos fenomenológiai gondolkodása világitott rá, hogy egyes problémák elveszithetik eredeti sajátosságaikat, majd belesimulnak egy nagyobb rendszerbe, de amennyiben újra lehetőség nyílik az eredeti strukturális múködésére, akkor visszaalakulhatnak.

Kulcsszavak: keresztén/keresztyén értékrendszer, egyházi szellemiség, egyházi tanitóképzés, keresztén/keresztyén pedagógus, elhívás, elhivatottság, közvetitómüvészet, eredeti beállitódás és hagyomány

DOI: 10.37205/TEL-hun.2019.ksz.02

\section{A magyar egyházi tanítóképzés főbb mérföldkövei}

Nursiai Benedek 529 táján, Róma és Nápoly között, Monte Cassino hegyén alapított kolostort. Monte Cassino kolostorában a bencés (azaz: Benedek-rendi) szerzetesek azon is dolgoztak, hogy újabb és újabb kolostorokat hozzanak létre Európaszerte. Így jutottak el hazánkba is a X. század végén. Minden kolostorban folyt olvasástanitás. A nagy kolostorokban általában két iskola múködött: egy belső iskola a leendő szerzetesek (oblátusok) számára, egy külső pedig a világi papok képzésére. A keresztény egyház szervezetének kiépítése együtt járt az egyházi iskolák megteremtésével, s ez kettős célt szolgált: klerikusokat képeztek, akik az egyházi 
szolgálat ellátásán túl világi értelmiségi funkciókat is betöltöttek. Szent István több kolostort alapított bencés szerzetesek részére. Ezek közül kiemelkedik a Szent Márton hegyi kolostor, amelynek első szerzetesei még Géza fejedelem hívására, 996-ban érkeztek ide. Letelepítésüket - mint ahogyan azt az 1001-ben megújított alapítólevél is tartalmazza - a királyság megerősítése (pro stabilitate regni) indokolta. Első királyunk nyolc püspökség alapításáról intézkedett (Győr, Veszprém, Pécs, Csanád, Eger, Vác, Nagyvárad, Gyulafehérvár). Ezeken a helyeken székesegyházi iskolák múködtek. A falusi papok megtanították mindazt a növendékeiknek, amit maguk is tudtak, de ehhez nem rendelkeztek pedagógiai-módszertani ismeretekkel. A közfelfogás úgy tartotta, hogy ha valaki tud valamit, akkor arra is képes, hogy azt másnak megtanítsa. Ez a pedagógiai alapállás az egész középkorra jellemző. A tanulásnak ez a módja a társadalmi felemelkedésnek is kiváló eszköze volt: szegény sorsú szülők gyermekeiből lehettek így megbecsült lelkipásztorok vagy akár tudós klerikusok.

A világi értelmiségi feladatot ellátó férfiak elnevezése először az 1320-as években bukkant fel oklevelekben. Literatusnak nevezték őket, ezt a korabeli magyar nyelvú iratokban a diák vagy deák szóval fordították. A literátusok képzettsége a hagyományos klerikus műveltség elemein túl (grammatika, diktámen, kompútusz) sokoldalú, gyakorlatias világi ismereteket is tartalmazott. A deákműveltség általános értelmiségi feladatokra felkészíton, nyitott ismeret- és készségrendszert jelentett.

A XVI. század pedagógiájára, nevelésügyére két eszmeáramlat hatott elemi erővel. Az egyik a humanizmus, mely a középkor klerikus műveltségének egyeduralmát megtörve ember-irányultságú kultúrát és emberléptékü pedagógiát hozott létre. A másik a reformáció, amely az egyház hierarchikus tekintélyéhez kötődő, kiüresedett hitélet helyett személyes indítékú, bensőséges, mélyen átélt vallásosságot - s ilyen alapozású pedagógiát - hirdetett. A reformáció térhódítása példátlan kihívást jelentett a katolikus egyház számára. A válasz nem sokáig késett. Az újjászülető katolicizmus a közoktatás, a pedagógia terén is máig érvényes értékeket teremtett. A protestánsok - egészen a XIX. századig - nem szerveztek külön tanárképző́ket. Közvetlen pedagógiai tapasztalatokat a „tógás” diákok (nagydiákok) praeceptorként szerezhettek. A katolikusok viszont külön képzőkben foglalkoztak a középiskolai tanári pályákra igyekvőkkel.

A XVII. században már új eszközök is rendelkezésre állnak: kialakul és fejlődik a gyermekgyógyászat, egyre elszántabb erőfeszítéseket tesznek az esendő gyer- 
meki életek megmentésére. A gyermekre már egyre inkább úgy tekintenek, mint önálló értékekkel rendelkező individuumra, aki figyelmet, törődést érdemel. Comenius a Nagy Oktatástanban négylépcsős iskolarendszert vázol fel, amelynek minden fokozata hat esztendeig tartó nevelést, képzést ölel fel. Apáczai Csere János a tanító személyiségéről ír, akivel szemben igen szigorú követelményeket támaszt! A Ratio előtt is voltak népiskolák - néptanítók, de a tanítókkal szemben nem nagy követelményekkel léptek fel. Rendszerint magasabb iskolából kimaradt diákok, kiszolgált katonák lettek tanítókká (Sebestyén, 1896).

A protestánsok a kollégiumi rendszerben már működő tanítói szolgálatot vállaló diákok célirányos kiművelésével igyekeztek lépést tartani az új követelményekkel (Kelemen, 2007). Debrecenben Buday Ézsaiás 1802-ben bölcsészeti tanfolyamon már didaktikát is tanított. Zákány József pedig, 1824-ben pedagógiai tanszéket mủködtetett. Továbbá Pápán is és Sárospatakon is bármelyik tanfolyam hallgatói hallgathattak neveléstani tárgyakat a főiskolán. Már a nagy protestáns gondolkodók, Luther és Kálvin is hangsúlyozták, hogy minden ember számára szükséges a népiskolai oktatás, amelyhez képzett tanítók kellenek. A néptanítók munkája akkor lehet eredményes, ha az emberek megértik és hasznosítani is tudják a saját életükben a tanultakat, hogy becsületes és lelkiismeretes polgárokként éljenek a világban. A puritán mozgalom angol és holland egyetemeken végzett képviselői közül Tolnai Dali János, Apáczai Csere János teremtettek kiemelkedő iskolákat. Marosvásárhelyen, Brassóban, Gyulafehérváron, Debrecenben olyan tanítók képzésére törekedtek, hogy „akik kikerülve a kollégiumból - tanácsot adnak a földművelő és ipari munkához, járatosak jogi, egészségügyi, pénzügyi kérdésekben is, valamint képesek az iskolákat a polgári fejlődés eszközévé tenni.” Újabb lendületet adott a pietizmus képviselőinek nevelési eszménye. Tessedik Sámuel törekvéseinek lényege a gyakorlati ember nevelése volt „a társadalmi szükségletek kielégítése céljából" (Szenczi, 2008, p. 9).

1845-ben a Systema Scholarum a képzőket két évfolyamúvá tette. A felállított tanítóképző intézetek még nem önálló szakiskolák, megmaradtak a fóelemi iskolákhoz kapcsolódó gyakorló tanfolyamoknak. A protestánsok is csak középiskoláik, kollégiumaik mellett, mellékesen foglalkoztak tanítóképzéssel.

A katolikus egyház 1818-ban Szepesváralján német nyelvü képzést indított. $A z$ első katolikus tanitóképző intézetet Pyrker László egri érsek állította fel 1828-ban, Egerben. 1829-ben az evangélikusok Sopronban alapítottak tanítóképzőt, 1839- 
ben a reformátusok Nagyenyeden, Debrecenben, Nagykőrösön; 1840-ben a katolikusok Budapesten, Szegeden, Miskolcon, Érsekújvárott, Nagykanizsán.

Az 1848-as forradalom gyökeresen át akarta alakítani a népoktatást, így a tanítóképzést is, de a szabadságharc leverése ezt elsöpörte. Az abszolutizmus korában továbbra is az osztrák minta dominált, de a tanítóképző tanfolyamok a főelemi iskolával maradtak összeköttetésben. Haladás, hogy a nevelés- és oktatástant is felvették tantárgyaik közé. A kántorképzés miatt nagy gondot fordítottak az énekre, zenére.

Az 1868. évi törvény szerint a tanítóképezdék önálló szakiskolák lettek. Gondot fordítottak mind az elméleti, mind a gyakorlati képzésre. Szerves kapcsolat alakult ki a gyakorló iskolával és legalább 2 holdnyi kerttel. Önálló tanári testülete lett, mely az igazgatóból, két rendes, egy segédtanárból s a gyakorló iskola tanítójából állt. A tanítóképezdébe olyan éptestű, 15 évet betöltött növendékeket lehetett felvenni, akik a gimnázium vagy reáliskola első négy osztályának ismeretével rendelkeztek. A tanítóképző intézet épp oly gondot fordít az általános műveltség fejlesztésére, mint a hivatásszerủ gyakorlati képzésre. Ehhez képest szabja meg a három évfolyam köteles tárgyait (Mészáros et al., 1999). Intézeteket tarthattak fenn az állam, községek, hitfelekezetek, társulatok, magánegyének. A felekezetek számára a törvény különösen előírta, hogy képzőiknek gyakorló iskolával kell rendelkezni, a törvény által előírt tantárgyakat megfelelő terjedelemben tanítsák, előírt vizsgáikat pontosan tartsák meg és ennek eredményéről a minisztert értesítsék (Osváth, 1939). Előírtak a képesítő vizsga mellett szigorlatot is a módszertani tárgyakból. Az intézmény vezetése kettős: az igazgató mellett az igazgatótanácsnak is jelentős szerepe volt. A diákok ellátásáról gondoskodnak, különösen a szegény sorsúakról (Osváth, 1939). Ugyanakkor az egyházak igyekeztek megőrizni felekezeti sajátosságukat. 1896-ban 66 képzőben 700 tanár kb. 5000 növendéket tanít. Ebből: 24 állami, 42 felekezeti. Tanítóképzéssel 47, tanítónőképzéssel 19 foglalkozik (Osváth, 1939).

Az egyházi képzők egyedi sajátossága a szokásrendszerükben is rejlett. Természetesen az egyházi intézmények gondolatkörét az állami tanítóképzők is a maguk szellemiségének megfelelően érvényesítették (Szenczi, 2008, p. 14).

Különbségek voltak azonban a diákok társas kapcsolatainak megítélésében, amely a magatartási, viselkedési követelményeket is befolyásolta. Nem nézték jó szemmel a diákok nyilvános szereplését, a táncmulatságokat és egyéb iskolán kívüli esetleges mulatozásokat. A nevelés legfontosabb tényezőjének tartották, hogy 
a növendékek a jótékonyság erényében gyakorolják magukat, s erőiket egyesítsék. Módszeres utasításokban foglalták össze a diákok kötelezettségeit, a különböző szervezeti formákban történő eljárásmódjait. A tanítási munkaformákat és módszereket is utasítások szabályozták. Ekkor vált feleslegessé a „noteszrendszer”. A XIX. század végétől jó néhány tankönyvet is bevezettek, de továbbra is több tanári kéziratot, kézikönyvet és jegyzetet használtak. E körülmény a képezdei oktatást annyiban gátolta, hogy a sok kézirat másolása vagy jegyzetelése a tanításból időt emésztett fel. ${ }^{1}$ A legfontosabb munkaformák közül a zenei képzéssel kapcsolatos foglalkozásokat említhetjük az első helyen. Az egyházi képzés legfontosabb területének tartotta a hallás és az éneklés fejlesztését. Szinte minden intézményben énekkar működött, melynek különböző rendszeres szolgálatokat (pl. temetés) kellett végeznie. A manuális tevékenység fontos területei voltak a rajztanítás mellett a kézimunkázás és a háziipari oktatás. Mivel a tanítók a falu gazdálkodásában is részesek voltak, így a gazdasági (például selyemhernyótenyésztés, méhészet) tevékenység ajánlott volt. A kulturális tevékenységhez és a szabadidő eltöltésére önképzőkörökben szervezték meg a diákok érdeklődésének megfelelő foglalkozásokat. Például olvastak, írásbeli dolgozatokat, élőszóbeli előadásokat, útleírásokat, természettudományi műveket, néprajzi gyüjtőmunkát végezhettek. Az önképzés munkáját támogatta az egyre több helyen létrejövő könyvtár is. Ezeken az alkalmakon készültek az iskolai, lakóhelyi ünnepségek rendelkezésére, egyházi alkalmak szervezésére. A tanári karok, mint ahogyan erről már korábban is említést tettünk, nagy hangsúlyt fektettek a fegyelemre, amely szintén szokásokon alapult. Minden intézmény rendelkezett fegyelmi szabályzattal, de sajnos a szabályzatokban leírtak megvalósítására a tanári kar eszközei sokszor elégtelennek bizonyultak. Ennek többféle oka is volt. A legelső ilyen probléma, hogy a növendékek különböző társadalmi rétegekből kerültek az iskolába 17-20 éves korig, az iskola azt feltételezte, hogy szinte minden növendék eljutott az önfegyelmezés fokára, ezért kezdetben felnőttként kezelték őket. Ennek következtében a tanári kar többször tanácstalan maradt egy-egy fegyelmezetlen diákkal szemben (Szenczi, 2008, p. 17-20).

\footnotetext{
${ }^{1}$ Érdekességként jegyzem meg, hogy ennek következtében a vezető testületek, pl. igazgatótanács megvizsgálta a tanulók tankönyvhasználatának ügyét, s felhívta a tanárok figyelmét, hogy az általuk készített vezérfonalakat lehetőleg nyomtatásban adják az ifjak kezébe.
} 


\section{A XX. századi egyházi tanítóképzés szellemisége, szakmai kortörténeti rekonstrukciója}

A trianoni békediktátummal megcsonkított országunk, kényszerpályára állított állam lett. Nem véletlen, hogy a megbénított ország útkeresése egyes egyedül ezekben az években - a kultúra erejében bízhatott. A „kultúrfölény” célkitűzése a nemzeti felemelkedés egyetlen útja volt, amelynek megvalósításához a nemzetnevelés gondolata fogalmazódott meg. A gondolat menete a XIX. sz. első évtizedeiből származik, Széchenyi István „lelkületéből” ered. Széchenyi szerint a magyarság jövendője csak egyetlen úton, a nevelés útján biztosítható. Ez a gondolkodás természetesen a korábbi évszázadokban is élt, valahányszor a nemzet jövőjére, az ifúságra gondoltak. Nagy kérdés volt azonban, hogy hogyan kell megvalósítani a nemzetnevelést (Szenczi, 2008, p. 21). Imre Sándor az akarati cselekvésben látta a megvalósulás útját, ehhez nemzeti tudatosság, a közös munkára való képesség és az erkölcsös életvitel szükséges. Ezen a ponton megkülönbözteti a nemzetnevelést, a nemzeti neveléstől. „A nemzetnevelés: a nevelés mivoltának, egyetemes céljának megjelölése, ekként minden nemzetre nézve azonos, de ha haladni akarunk e felé az egyetemes cél felé, akkor ez a nemzetnevelés a földnek két pontján nem lehet azonos, hanem mindegyik nemzetnek körében másnak és másnak kell lennie, annak a nemzetnek egyénisége és helyzete szerint. Ezért azt mondhatjuk, hogy a nemzetnevelésnek minden egyes nemzet körében nemzetivé kell válnia. Ezek szerint ez a kifejezés: nemzeti nevelés, jelenti azt, hogy alkalmazkodom az én nemzetemnek állapotához, megkeresem az én nemzetem elé tüzhető célt, és úgy dolgozom efelé a cél felé haladva, ahogyan épen itt lehet és ahogyan épen itt kötelesség." (Imre, 1920, p. 55).

A Horthy-korszak közoktatásügye a XIX. század utolsó harmadában kialakult iskolarendszer átvételén és további fejlesztésén alapult. Az oktatásügy irányítása hagyományosan a vallás- és közoktatásügyi miniszterek feladatkörébe tartozott. Gróf Klebelsberg Kunó 1922-től 1931-ig irányította a tárca munkáját. Klebelsberg az oktatást, a tudományt és a kultúrát a nemzetpolitika stratégiai ágazatainak tekintette, és ennek megfelelően kiemelt támogatásban igyekezett részesíteni (Szenczi, 2008, p. 22).

Egyik legfontosabb feladatának Klebelsberg a népiskolai oktatás fejlesztését tartotta. Erre a költségvetési egyensúly megteremtése után nyílt mód. 1921-ben a 6 és 15 év közötti korosztály iskolalátogatási kötelezettségét megerősítették. A 6 osztályos elemi után a 3 osztályos továbbképző népiskolákat kellett látogatni. Kle- 
belsberg idején felmerült, hogy ezt a $6+3$-as rendszert $8+2$ osztályos rendszerré kellene fejleszteni (Mészáros et al., 1999).

Már Kálvin János írásaiban is megfogalmazódott az Úr hatalma a gondviselés kiteljesülésében: „mivel a történések rendje, értelme, célja és szükségszerűsége többnyire Isten tervében van elrejtve és emberi értelem nem foghatja fel, mindaz ami egész biztosan Isten akaratából történik, véletlennek látszik. [...] Megmarad azért szívünkben szilárdan az a meggyőződés, hogy semmi olyan nem történhetik, amit az Úr előre ne látott volna." (Kálvin, 1986, p. 45).

A kálvini tanítás szerint a gondviselés ellentétben van a szerencsével, a véletlennel, így az anankológia szempontjából vizsgálva minden történést „Isten titkos terve igazgat." A protestáns tanítás szerint az ember a lélek képességei szerint jár el. Az emberi léleknek két képessége van, az értelem és az akarat. Az értelem képessége megállapítja, hogy a tárgyak, tények stb. közül, melyik érdemes a helyeslésre, melyik a helytelenítésre. Az akarat képessége pedig kiválasztja és követi a jó utat. Ezért nagyon fontos az uralom eszmei alátámasztása, hogy ne kelljen az erőszak tömeges alkalmazásával élni, hanem az emberi önuralom és akarat az engedelmesség felé irányuljon. A köznevelés gyakorlata során még hatással bír $B a-$ vinch keresztyén ideológián alapuló nevelési rendszere. Itt felmerül a pedagógiai értelemben használt fegyelem kérdése. A herbarti kategórikus imperativus ember képes erre. Max Weber szerint pedig a fegyelem az az esély, hogy az emberek egy begyakorlott beállítottság alapján megfelelő sokaságban automatikusan engedelmeskednek. Természetesen ehhez legitim uralom szükséges.

A Trianon utáni helyzet az egyházak életére és szellemiségére is kihatott. Erdély, Felső-Magyarország, a protestantizmus történésének nagy színterei, határon kívül rekedtek. A magyar református gyülekezetek csaknem fele az elcsatolt részekben élt. A politikai döntések a felekezetek sorában is nagy zavart keltettek. A bolsevista veszély elhárítása céljából a győztes hatalmak a konzervatív szellemiséget, filozófiát szorgalmazták Magyarországon, ugyanakkor gazdasági támogatást nem adtak hozzá. Erdélyben is megnövekedett a katolikus egyház tekintélye, a protestánsokat a liberális szellemiségük miatt sok bírálat érte. A kommunizmus szellemiségével szintén nem értettek egyet az egyházak. A teológiai szakirodalmakban egyértelmúen állást foglaltak a bolsevizmus ellen. Az egyházi iskolákban hangsúlyosan kezelték a Trianon utáni életérzés problematikáját. A kulturális és az erkölcsi fölény hangsúlyozásával a lelki szenvedésünket a Krisztusi szenvedéshez hasonlóan szimbolizálták. A pszichológia, filozófia és a pedagógia területén: 
Mitrovics Gyula, Trócsányi Dezső, Karácsony Sándor munkái gazdagították a keresztyén szellemiségű nevelést a kiterjedt iskolarendszerben (népiskolák, polgári iskolák, gimnáziumok, tanító- és tanítónőképzők, akadémiák és doktori iskolák). $\mathrm{Az}$ iskola és a társadalom viszonyrendszerét a klasszikus keresztyén bölcselet alapján strukturálták. Legfőbb célként a múlt értékeinek a mai emberhez való eljuttatását tekintették (Szenczi, 2008, p. 26-27). Fontosnak tartották: „a keresztyén bölcselet nemcsak történeti jelentőségű, hanem élő rendszer, mely képes folyton új tudásanyagot befogadni s az elvi igazolás kritikáján átszűrve értékesíteni. Korunk súlyos társadalmi válságában, melynek mélyén a korlátlan érvényesülést követő önérdek s az egyént megsemmisítő fenyegető tömeg-szellem ellentéte feszül, nem merülhet feledésbe az a társadalmi rendszer, mely a kreatív »kultúrlélek« önmagára eszméléséből született s mely a közösségi tudat ébrentartása mellett a személyiség javait is biztosítva, ma a jobb jövő, a kiengesztelődés és a kibontakozás útját hivatott megjelölni." (Kecskés, 1938, p. 3).

A keresztyén társadalomelmélet tudományos igénnyel rendszerezi a XX. század első felének magyarországi problematikáját. Pauler Ákos tudományrendszerezés-tani elméletéhez hasonlóan, a metafizikai redukció alkalmazásával tárta fel (Somos, 1999).

\section{A nagykőrösi tanítóképzés sajátosságai}

A tanítókat „kiképző” mintaiskolák rendszere után az első református képzők, 1839-ben Debrecenben, Nagyenyeden és Nagykőrösön indultak. Az 1848/49. szabadságharc után pedagógiailag is megalapozott rendszerek jöttek létre. Az igazgatók nagy lendülettel láttak hozzá a programok megvalósításához.

Nagykőrösön Szigeti Warga János, Nagy László iskolavezetői munkája, vagy Debrecenben Zákány András, a protestáns pedagógiai kultúra megalapozójának szellemi hagyatéka indította el igazából a református tanítóképzést. Az új intézmények szellemi hátterüket a protestáns kollégiumi rendszerből merítették. Nagy erőt sugároztak a debreceni, a sárospataki, a székelyudvarhelyi, a marosvásárhelyi kollégiumok. Az erdélyi iskolamesterek közül ebben a nehéz időben kiemelkedett érdemei voltak az udvarhelyi Kis Ferencnek, akinek tanítványa volt Orbán Balázs is, vagy a marosvásárhelyi Horváth Gáspárnak és Menthovich Ferencnek. Menthovich később Nagykőröst baráti szálakkal is összekötötte Marosvásárhellyel, Arany fános pedagógiai nézeteit is népszerüsítve. Arany nevelési célja: a lelkiismeretes ember, a keresztyén nevelésben ma is érvényes alapértelmezés! (Lásd a 
„Domokos napra” című versét.) Szigeti Warga János Nagykőrösön Fáy András felhívó szavára különös figyelmet fordított a philosophikus cursus növendékei közül azokra, akik tanítók akarnak lenni. Ezzel szakmailag megalapozta tanítóképezde megnyitását. Bakos Ambrus Nagykőrös főbírája pedig szervezőként fordult a „Dunamelyéki Superintendentiához”, hogy alapítson „Collegiumot”, hiszen Kőrösön két professzor is van Balogh Mihály és Warga János személyében, sőt 1839. október 4-én megérkezett Karika Pál a gazdaság professzora is (Osváth, 1939). Megszületett az első igazi alapító levél (már egy próbálkozás 1837-ben volt) 1839. október 4-én az Oeconomiko-paedagogicum institutumról. (Szenczi, 2008, p. 10).

A nagykőrösi tanítóképzés történetéről elsőként Nagy László majd dr. Kiss Áron intézeti igazgatók tudósítottak. Hegymegi Kiss Kálmán pedig első írásában az intézet kezdeti 20 esztendejéről számolt be 1839-től 1859-ig, majd 1896-ban megírta „A Nagykőrösi és Dunamelléki Református Tanítóképző Intézet monográfiája” címủ munkáját. A magyar városok monográfiája témájú sorozatban pedig Galántai Fekete Béla méltatta a dualizmus korszakának egyik kiváló képző intézményét. Szigeti Warga János után Hegymegi Kiss Kálmán nevéhez füződik az iskola felvirágoztatása.Az iskola részletesebb történetét - a „Képezde” fennállásának 100 éves évfordulójára, 1939-ben Osváth Ferenc nyugalmazott tanár, címzetes igazgató írta meg. A könyv eredeti címe: A nagykőrösi református tanítóképzöintézet története. A munkát két részben tervezték. Az első rész az 1839-1914 közötti szakaszról szól, a második az I. világháború kitörésétől 1939-ig foglalta volna össze 35 esztendő tevékenységét. Ez a rész viszont napjainkig sem készülhetett el... (Szenczi, 2008)

A felsorolt művek alapján elmondható, hogy nagy változást eredményezett az intézmény életében az egyházkerületi intézkedések körültekintő oktatáspolitikája. Török Pál pesti egyházmegyei esperes (később püspök) sürgetésére létrejött a pesti theológiai intézet, 1855-ben. Szigeti Warga János igazgató viszont Nagykőrösön az 1855/56-os tanévet úgy nyitotta meg, mint a tanítóképző igazgatója. „Tehát nekem szerencsém volt a jelen iskolai évet nemcsak úgy megnyitni, mint főgimnáziumi, hanem mint praeparandiai tanévet is. Igenis, mint praeparandiai tanintézetet is nyitottam meg ezt, tehát elértem, mire 22 év alatt folyvást törekvém: jelesül, hogy a praeparandia nálunk mint önálló intézet alapíttassék meg, hasonlóan nemcsak a külföldi, de a hazai cs. K. képezdékhez is. Elértem keblem leghőbb vágyát, miszerint tanintézetünkben néptanítók, az álladalom legjelentékenyebb tisztviselói képeztetnek, mert a népiskolatanítók vallásosságáról, értelmes belátásától és 
ügyességétől föltételeztetik a nép vallásossága, értelmessége és életrevalósága, szóval jelen és túlvilági boldogsága. A jó népiskolatanító megbecsülhetetlen áldás, a rossz ellenben a legkárhozatosabb átok! Vajmi sok erő elvész a népben az értelmetlenség, az ügyetlenség és a munkához való szoktatás alkalom hiánya miatt! Hányszor vesz a néptömeg ereje a nevezett hiányok miatt rendeltetése feladatával egészen ellentétes irányt? Hányszor süllyed értelmetlenség és munkátlanság által erkölcstelenségbe és anyagi szegénységbe alá? Így a nép, mely az álladalom erős magva tartoznék lenni, lehet s lesz annak megemésztője, holott vallásos képzettsége, értelmessége, fóleg munkához, szorgalomhoz és pedig oly szorgalomhoz szoktatás által, mely a természettel barátkozik, őt azzá lehet képezni, ami úgy mint állam magvává. Erre pedig legtöbbet tehet egy vallásos, ügyes, kiképzett néptanító." (Osváth, 1939, p. 63). Ezt követően a gimnáziumi igazgatóságtól a képző igazgatósága levált, miután Nagy László kisújszállási gimnáziumi tanárt a tanítóképző élére meghívták. Az új igazgató nagy buzgalommal kezdett a tanítóképzés rendszerének kialakításához. 1860-ban elkészült a tanterv, amely a képzés idejét 3 évre emelte, így figyelembe vette Eötvös József 1868. évi törvénycikkét. Két év múlva létrejött a tápintézet. 1864-ben a zene és az ének tanítására önálló tanszéket szerveztek. 1869-ben a fenntartó testületek felállították a gyakorlóiskolát, amely attól kezdve a tanítóképző intézet szerves része volt. Nagy László igazgatót királyi tanfelügyelővé nevezték ki, így utóda Hegymegi Kiss Áron budapesti tanár lett, aki azonban csak 1875-ig állt az intézet élén, mert őt, pedig Budára hívták meg igazgatónak. Távozása után sajnos Magyar Antal nem sokáig tölthette be az igazgatói széket, mert infarktus következtében váratlanul meghalt. Öt majd Hegymegi Kiss Kálmán követte az iskola élén, aki hosszú ideig, 1913-ig látta el igazgatói tisztet.

Az intézet megalapításában és történetének első korszakában szakmailag tehát Szigeti Warga Jánosnak jutott a sorsdöntő szerep. Majd Hegymegi Kiss Kálmán 31 éven keresztül vezette az iskolát, őt pedig egy újabb nagy egyéniség, Váczy Ferenc követett az igazgatói székben (Szenczi, 2008).

Az új életre kelt tanítóképző a nevelés tekintetében és szellemiségében is arra törekedett, hogy a leendő tanítók lelkében a tiszta erkölcsiség, vallásosság, egyházias jellem és érzület teljesedjék ki. Fontos nevelési terület volt a nemes közérzület kialakítása, amelyet a közéletiség katalizátorának is tartottak. A korabeli Értesitők szerint az 1850-es évek végétől kezdve folyamatosan elemzik a vallásos hazafias nevelés állapotát, a tudományos nevelés szintjét, az egyházi gyakorlati 
jártasságot; pl. a szolgai alázatosságot, a tanítói hivatalhoz való tisztességes viszonyt, a templomi és temetési szolgálatokat. A tanári testület rendszeresen ellenőrizte az úrvacsorai rend gyakorlását. Filó Lajos, aki 1861-1905-ig töltötte be az igazgatótanácsi elnöki tisztét, rendszeresen ifjúsági istentiszteleteket tartott Ádám Gerzson főgimnáziumi igazgatóval együtt.

\section{A keresztyén szellemiség tükröződése a nagykőrösi képző értesítőinek, évkönyveinek áttekintése alapján}

A nagykőrösi képző történetét 1839-től, az alapítástól az I. világháború időszakáig Osváth Ferenc tanítóképezdei tanár tekintette át (Osváth, 1939). Az intézet Trianontól folytatódó szakaszának megírására dr. Juhász Bélát, szintén az intézmény tanárát kérték fel. Juhász Béla fiatalon került a képzőbe, Imre Sándor javaslatára. A neveléselmélet tanításával bízták meg, hiszen a „kis Imre Sándor” - ahogyan őt nevezték társai - kiváló ismerője volt a pedagógiai elméletének, a nemzetnevelés és a keresztyén értékeken alapuló személyiség formálásának. Több tanulmányában is bizonyította ez irányú elkötelezettségét. A képző történetének 2. részét azonban - nagy valószínúséggel - nem írta meg sem Juhász Béla, sem Osváth Ferenc. Többféle indok hallható a régi diákoktól, pályatársaktól, azonban a jelenlegi munka szempontjából ezek az okok nem fontosak. Annál inkább lényeges kérdés, hogy a trianoni időszaktól, a kommunizmus magyarországi kibontakozásáig milyen nevelési rendszere, szellemisége érvényesült az egyházi képzésnek?

Az első forrásanyag 1927-ből származik, majd szinte évenkénti megjelenésben találkozhattunk az Értesitókkel. A nagykörösi képző 100. éves évfordulója alkalmából „Évkönyv” jelent meg az 1939/1940. iskolai évről, és 1947-ig évente volt olvasható.

Mintegy 40 év intézménytörténetét az Évkönyvek alapján többféleképpen is feldolgozhatjuk. Elképzeléseink szerint egyrészt a kronológiai történések sorát, másrészt viszont a témakörök szerinti szerkesztést választhatjuk. A részletesebb kifejtés előtt azonban kiemeljük azokat a magyarországi történéseket, amelyek lényegesen befolyásolták egy-egy tanév leírását, vagy egy-egy tevékenységi forma létrejöttét, illetve megszűnését. Szintén érdemes elemezni a fenntartó egyháztörténeti sajátosságait. (Szenczi, 2008, p. 28-32). Ezek közül azt a neveléstörténeti érdekességet, hogy a két fenntartó: a Dunamelléki Református Egyházkerület és a Nagykőrösi Református Egyházközség igen nagy összhangban irányította a Képezdét, valamint a Szegedi Egyetem professzora, Imre Sándor mintegy negyed év- 
századon át, haláláig, 1945-ig „pedagógiai atyja”, szakmai irányítója volt a képezdei munkának. Ravasz László püspök teljes egészében rábízta, a neveléstudományi irányítás mellett a teológiai értelemben vett egyházi felügyeletet is. Mint egyházkerületi tanügyi előadó, minden egyes tanévnyitás és zárás, valamint a képesítő vizsgálatok alkalmával jelen volt és aktívan közreműködött a napi munkában is. Rendszeres előadásaival mind a tanári értekezleteken, mind az ifjúság körében nagy népszerűségnek örvendett.Itt jegyezzük meg, hogy a korszak másik nagy református pedagógiai gondolkodója, Karácsony Sándor igaz kevesebbet járt Nagykőrösön, de látogatásai mély nyomot hagytak az ifjúság körében (Szenczi, 2008, p.40-45). Például 1936. március 20-21-én tartott „Csendes Napok” alkalmával tartott előadást A mai úrvacsoránk címmel (Értesíto, 1935-36). „A csendes napokat folyó évi március 20-án és 21-én tartottuk meg a gimnázium és a polgári fiúiskola növendékeivel együtt. A csendes napok a templomban áhítattal kezdődtek, melyet Patonay Dezső református lelkész végzett, utána pedig Hegyi Sándor gimnáziumi vallástanár hívta fel az ifúság figyelmét a csendes napok jelentőségére. Az előadásokat és az azt követő megbeszéléseket három csoportban tartottuk. Intézetünk növendékei számára a következő előadások voltak: Református kegyesség és önnevelés (Hegyi Sándor), Jézus és én (dr. Incze Gábor), A katholicizmus, pragmatizmus és a kálvinizmus (Paczolay István), A mi úrvacsoránk (Karácsony Sándor). A reggeli áhítatok után bibliatanulmányozás is volt mindkét nap, tárgya az „Úri ima” megbeszélése volt. A csendes napok úrvacsorai istentisztelettel végződtek, melyet Göde Lajos református lelkész végzett.” (Értesítő, 1936).

Karácsony Sándor indirekt jelenléte a továbbiakban is dominált az ifjúság körében. „A diákok a Soli Deo Glória (SDG) keretében 3 munkacsoportban is tevékenykednek a Karácsony Sándor-i szellemiségben." (Értesítő, 1936).

A korszak két meghatározó teológiai - pedagógiai gondolkodója mellett megemlíthetjük, hogy az állami hivatalos képviselet is rendszeresen jelen volt Nagykőrösön. Minden képesítő vizsga (tavaszi és őszi is) alkalmával a Vallás és Közoktatási Minisztérium vezetői is jelen voltak, 1927 őszén maga Klebelsberg Kunó miniszter, majd többször is Barabás Tibor főigazgatósági szakelőadó, de a közoktatásügyi kormányzat képviseletében járt itt Mitrovics Gyula debreceni tanszékvezető professzor, vagy Hóman Bálint képviseletében Jalsowiczky Károly államtitkár, a későbbiekben Rozsondai Zoltán tanügyi tanácsos. 1928-ban az iskolán kívüli népművelési előadóképző tanfolyam szervezésére is sor került. Ezt a tanfolyamot Pest-Pilis-Solt-Kiskun vármegye iskolán kívüli népművelési bizottsága 
rendezte az intézettel szoros kapcsolatban oly módon, hogy a vármegye alispánja a tanfolyam vezetésére az intézet igazgatóját, támogatására pedig a nagykőrösi református egyházat, illetve a tanítóképzőt kérte fel. Az igazgató-tanács készséggel állott a nagyjelentőségű ügy szolgálatába. „A tanfolyam szeptember 5-dikétől, 25-dikéig tartott. A vármegye területéről 74 tanító hallgatója volt, akik részére 20 előadó 84 órában ugyanannyi előadást tartott. A befejezés a szept. 25-i ünnepélyes záró előadáson történt meg, amelyen megjelentek: Klebelsberg Kunó gróf, vallás és közoktatásügyi miniszter, Preszly Elemér dr. Pest'vármegye főispánja, Agorasztó Tivadar Pestvármegye alispánja, Nevelős Gyula dr. miniszteri osztálytanácsos, Dezső Kázmér polgármester és az érdeklődők nagy számban. Ez alkalommal a nagykőrösi református egyház és tanintézetei képviseletében Patonay Dezső lelkész üdvözölte a miniszter úr őnagyméltóságát, Váczy Ferenc igazgató pedig beszámoló, illetve ünnepi beszédet mondott." (Értesítő, 1928).

Az énekkari, kántori rendezvényeken Kodály Zoltán zeneszerző is vendég volt. „Nagy meglepetés volt a nagykőrösi énekkultúra kibontakozása, ami Márton Barna református kántor pompás karmesteri rátermettségének és alapos nevelő munkájának érdeme. Az ünnepi hangversenyen két kitűnő együttessel állt ki a porondra: a református gimnázium gyermekkarával és a tanítóképző-intézet férfikarával. $\mathrm{Az}$ utóbbi kórus élén Bartók: Négy régi magyar népdalán kívül megszólaltatta a középső tételét annak az »Elmult időkből« c. hatalmas új kórustriptichonjának, amely a magyar zeneköltő legmegrendítőbb kiáltása a magyar föld elárvult, de elárvultságában is fölséges népéért." (Pesti Napló, 1937, ápr. 20.).

A háborús évek kivételével is rendszeresen országos, megyei rendezvényeket is szerveznek, az intézmény több alkalommal is vállalta a megyei szakmai tanfolyamok intézéseit, továbbképző alkalmakat. „A nagykőrösi értekezlet: A Dunamelléki Református Egyházkerület tanítóképzőjének tanárai a f. iskolai évben június hó 6-án Nagykőrösön gyűltek össze közös értekezletre dr. Imre Sándor egyetemi tanár, egyházkerületi tanügyi előadó elnöklete alatt. Ez volt a második ilyen összejövetel, amelyen mindkét intézetet érdeklő ügyeket tárgyaltunk meg oly módon, hogy az elvi megállapodás keretein belül mindkét intézet egyéniségének megfelelően oldhatja meg a felvetett kérdéseket. Az értekezlet jelentőségét nagy mértékben emelte annak tárgysorozata s az a körülmény, hogy mindkét tanintézet igazgató-tanácsa képviselve volt és pedig a kecskeméti dr. Hetessy Kálmán egyházi, Szeless László világi, a nagykőrösi Patonay Dezső egyházi és Gáll Dezső kormányfótanácsos, világi elnökökkel. Az értekezlet a következő ügyekkel foglalko- 
zott: a két tanítóképző építkezésének ügye; az év végi vizsgálatok szervezeti, pedagógiai és adminisztratív szempontokból; a gyakorló iskolák óraterve; szaktanárok látogatásai és több kisebb anyagi természetű ügy. Ezek között különösen az első a jelentős, mert ennek sikeres megoldásától függött mindkét, de különösen a nagykőrösi tanítóképző további fejlődése, sorsa (Értesítő, 1928).

A Teológiai Akadémia kezdeményezésére pedig lelkésztanító tanfolyamot indítottak több éven keresztül. Az események alkalmával a megyei vezetők, többször a főispán is vendége volt az intézménynek. A Teológiai Akadémia professzorai, pedig állandó jelleggel rész vettek a képzésben és a képesítő vizsgálatokban. Az 1934. év első felében végzett előkészítő munkálatok lehetővé tették azt, hogy lelkész-tanító tanfolyam is induljon. „Erre az alkalomra lejött hozzánk dr. Ravasz László püspök, dr. Imre Sándor egyetemi tanár, egyházkerületi tanügyi előadó és dr. Sebestyén Jenő theol. Igazgató társaságában. A megnyitó ünnepély délelőtt 11 órakor folyt le a templomban. Gyülekezeti ének után dr. Sebestyén Jenő igazgató átadta az okleveleket a segédlelkészeknek, illetve a hallgatókat a tanítóképző-intézet igazgató-tanácsának. A tanítóképző igazgatója az igazgató-tanács megbízásából átvette a hallgatókat és alkalmi beszédben ismertette a tanfolyam keletkezésének, megszervezésének okát és célját. - Végezetül dr. Ravasz László püspök meleg szavakkal ajánlotta a hallgatókat az intézet és a gyülekezet szeretetébe, jóakaratú támogatásába. A tanfolyam szeptember hó 17-én megkezdte múködését és szabályszerű szüneteket kivéve megszakítás nélkül folytatta az iskolai év befejezéséig" (Értesítő, 1935).

Külön is kiemelhetjük az intézmény fennállásának 100. évfordulójának eseményeit (Szenczi, 2008.p.32). Az ünnepi események 1938. október 15-én kezdődtek el és gyakorlatilag a „101. év” végéig tartottak. Az intézmény fennállásának 101. esztendejében gazdag tartalmú Évkönyvet is kiadtak. A legnevezetesebb esemény, hogy maga a Kormányzó, Horthy Miklós magas kitüntetést adott át. A 25 éves igazgatói tevékenység elismerését a tanügyi főtanácsosi cím adományozásával fejezte ki Váczy Ferencnek. Juhász Béla pályatárs a Nagykőrösön tartott jubileumi ünnepélyen méltóképpen összegezte a képző és Váczy Ferenc szellemi összetartozását. „Akinek megünneplésére itt egybegyülekeztünk, annak személyét vagy a tanítóképző-intézetet Nagykőrösön említeni már régóta egyet jelent. Egy fogalommá nőtt össze a munkahely és az elöljáró munkássága." (Évkönyv, 1940). 


\section{Az egyházi képzők szellemisége, pedagógusképe a XXI. század elején}

\section{A pedagógiai mesterség - „közvetító müvészet”}

Szenczi Árpád Professzionális nevelés - értékközvetítés társas-lelkületi alapon c. könyvének 12. fejezetében komplex módon fogalmazza meg a mai pedagógusképet. A fejezetben több keresztén/keresztyén szemléletű neveléstudóstól is idéz (Szenczi, 2018). Például újszerűen értelmezi a pedagógus név származását. A gyermekkísérő rabszolga, a szolgáltató, segítő pedagógus kép helyett, azt az erotikából is eredő szeretetet, azt a küzdelmet emeli ki, amely lényegesen különbözik a szülői szeretettől. Ez a küzdelem a megértésért, a tudás megszerzéséről, a közvetítés minőségéről szól. Legyen az tananyag, vagy akár a másik ember megértése. Fináczy Ernő Didaktika című munkájában a következőket olvashatjuk: „Felmerülhet itt mindjárt az a kérdés, vajon lehet-e egyáltalán valakit megtanítani a tanításra, $\mathrm{s}$ szükséges-e ezt megtenni. A tanítás képessége, a tanítani tudás természeti adomány. Ha valakiben nincsen meg ez az adomány, nem lehet jó tanító, tehát egészen hiába akarjuk megtanítani a tanításra. Ha pedig megvan benne ez az adomány, szükségtelen a didaktika: a veleszületett didaktikai tehetség ösztönszerü biztonsággal fogja vezetni azt, akinek tanítania kell. Beszélnek ily összefüggésben az oktatás művészetéről. Művésznek tekintik a tanítót, a lélekformálás művészének. Márpedig művész nem lesz, hanem születik." (Fináczy, 1935, p. 161).

Ha a pedagógus elhivatottnak érzi magát erre a feladatra, akkor képes véghezvinni kitűzött céljait, elképzeléseit. Az elhivatottság elsődleges jellemzői:

- pedagógiai szeretet,

- hit a kulturális és szociális értékekben,

- a gyermekkel szemben érzett felelősségérzet.

Számolnunk kell azzal a ténnyel is, hogy mint bármilyen pálya esetén, a pedagógusi pályán sem mindenki elhivatott, több esetben szakmagyakorlásról van szó.

Karácsony Sándor szerint: „A pedagógus nem lehet elkeseredett, megtorpant ember, mert a pedagógusnak egyetlen karizmája van: a jövőbe vetett hit optimizmusa." Az iskola értékrendjét, belső klímáját és a környezetre gyakorolt hatását egyaránt a benne tanító pedagógusok határozzák meg. A pedagógus nem csupán ismeretátadó, hanem rendkívül fontos szerepe van az értékközvetítésben, a társadalom által megkövetelt normák elsajátításában. Tevékenységével, személyiségének megnyilvánulásaival, teljes iskolán belüli létével visszatükrözi, és sajátos módon újratermeli azokat az értékeket, mintákat, amelyek az iskolán kívüli világból 
erednek. A tanítói munkához szükséges ismeretek, jártasságok, készségek tanulhatók és ennek megfelelően kialakulnak azok a képességek, amelyek a pálya eredményes műveléséhez szükségesek. Ugyanakkor minden nevelői tevékenységen alapvetően átüt a nevelő személyisége, annak érettsége, „minősége”. A nevelőt elsősorban nem szaktudása, hanem személyisége teszi jó nevelővé. Fontos a nevelésben a tekintély, de csak az emberi értékeken alapuló tekintély, amely a gyermekekhez füződő pozitív érzelmi viszonyon alapul. Akkor tud a pedagógus meggyőző lenni, ha tud úgy gondolkodni, mint tanítványai. Képesnek kell lennie arra, hogy a gyermekek gondolatmenetébe beilleszkedjen. Ezzel elkerülheti azt, hogy elóítéletei alakuljanak ki, illetve, hogy sztereotípiákban gondolkodjon. A pedagógusmunka alkotó jellegű, ezért nyitott, kreatív, alkotó személyiségek felelnek meg legjobban a nevelés funkciójának. A pedagógus számára elengedhetetlen a divergens gondolkodás, melynek jellemzője a rugalmasság, könnyedség, eredetiség. Fontos jellemzője még a pedagógus személyiségének a hivatástudat.

A keresztyén lelkületü pedagógus jellemzői a krisztusi, Krisztushoz tartozó attitüdök. Tehát a keresztyén pedagógus olyan ember, aki Jézus Krisztus követője, tanítványa lett. Keresztyén pedagógusok közös vonásai : értékrendjüket a bibliai értékrend határozza meg. Számára a legfontosabb érték a hit, minden más érték csak ezután következhet (a jó cselekedetek, a tudomány, a mértékletesség, a türés, a kegyesség, a szeretet). A keresztyén nevelőnek reális önérték-tudattal kell rendelkeznie. Ez a józan önértékelés mentheti meg attól, hogy magát le-, illetve túlértékelje a tanító. A gyerekek szempontjából sem mindegy, hogy milyen mintát követnek. Ugyancsak fontos ismertetőjegye a keresztyén pedagógusnak a lelki kisugárzása, a mozgása, gesztusai, megjelenése, ruházata, frizurája, arckifejezése, beszéde. Ha a gyerekek saját bőrükön tapasztalják a megbocsátás, a szeretet, az újrakezdés lehetőségének feltétel nélküli biztosítását, vágy ébredhet bennük nevelőjük „legfóbb támasza” megismerésére. A keresztyén pedagógus személyével kapcsolatban elvárható még a rendezett magánélet, erkölcsi tisztaság. A keresztyén nevelő olyan egyéniség, akinek nem az egyéni karrier számít, hanem az elhívás, az elhivatottság, akit toleráns magatartás, empátia, önzetlenség, lelkiismeretesség jellemez. A keresztyén pedagógus a gyermekre úgy tekint, mint akit az Úrtól kapott felelősséggel tisztel, szeret, és akire odafigyel. 


\section{Irodalom}

Balogh, F. (1904). A Debreceni Református Kollégium története. Hoffmann és Kronovitz Ny.

Bölcskei, G. (1988). A kezdetektől a váradi iskola beolvadásáig. In: Barcza, J. (Ed.): A Debreceni Református Kollégium története. (pp. 9-42) MRE Zsinati Irodájának Sajtóosztálya.

Donáth, P. (2008). „A magyar múvelődés és a tanitóképzés történetéből 1868-1958”. Budapest: Trezor Kiadó. https://mek.oszk.hu/08 200/08 254/ (2007. 12. 27.)

Fináczy, E. (1935). Didaktika. Studium Kiadó.

Imre, S. (1943). A nemzetnevelés fogalma. Társadalomtudomány (Különlenyomat), (1-2) Ráday Levéltár C/39. I/13.

Imre, S. (1920). Népiskolai neveléstan. Studium Kiadó.

Juhász, B. (1937). A református népiskolai nevelés legfóbb kérdései. Nagykőrösi Ref. Tanítóképző Intézet.

Karácsony, S. (1985). A magyar észjárás. Magyar Hírmondó. Magvető Kiadó.

Kálvin, J. (1986). Tanitás a keresztyén vallásra. MRE Zsinati Irodájának Sajtóosztálya.

Kecskés, P. (1938). A keresztyén társadalomelmélet alapelvei. Szent István-Társulat Kiadása.

Kelemen, E. (2007). A tanító a történelem sodrában. Tanulmányok a magyar tanítóság 19-20. századi történetéből. Pécs: Iskolakultúra.

https://mek.oszk.hu/05 200/05 223/ (2007. 12. 27.)

Pesti napló. 1937. 04. 20.

Sebestyén, Gy. (1896). Elemi iskolai tanitó- és tanitónőképzésünk fejlődése. Lampel Kiadó.

Molnár, J. \& Tóth, J. (Ed.) (1990). Székelyudvarhelyi Benedek Elek Tanitóképző rövid története.

Mészáros, I. (1981). Az iskolaügy története Magyarországon 996-1777 között. Akadémiai Kiadó.

Mészáros, I., Németh, A., \& Pukánszky, B. (1999). Bevezetés a pedagógia és az iskoláztatás történetébe. Osiris Kiadó.

Nagykőrösi és Dunamelléki Református Tanítóképző Évkönyvei

Nagykőrösi és Dunamelléki Református Tanítóképző Értesítői

Osváth, F. (1939). A nagykőrösi református tanitóképző-intézet története.

Somos, R. (1999). Pauler Ákos élete és filozófiája. Paulus Hungarus-Kairosz Kiadó. 
Szenczi, Á. (2018). Professzionális nevelés - értékközvetítés társas-lelkületi alapon. 12. fejezet, A pedagógus személyisége, egyénisége, karizmatikus beállítódása, legfontosabb kompetenciái (pp. 291-304) Eötvös József Könyvkiadó.

Szenczi, Á. (2008). A nagykőrösi tanitóképzés szellemiségének történeti rekonstrukciója. Református Tanítóképző Főiskola.

\section{Chapters from the history of the Hungarian elementary Christian school teacher education}

Educational systems of secondary teacher training institutes operating until the late 1950s have been investigated by the academic staff of catholic and protestant universities for three decades. The aim of this research was the following idea: "For the independent operation of the reorganized institutions it is essential to reveal the historical past, to examine the mentality and the educational system of similar teacher training institutions, to compare their theoretical and practical training, and to use these information as lessons to be drawn".

The present study investigates the roots of this mentality while searching for potentials for the enrichment of the present training programme. The aim of the study is to reveal such continuities and correspondences that can verify the assumption that the present teacher training could preserve its original mentality and traditions even after the thirty-five years of forced intermission. During the valuation of results it was proven that the mentality of church education can reconstruct, because it is a synthetic force.

The initial hypotheses are tested according to the principle of prudentia by means of a number of research methods.

As a conclusion, the study establishes that those that were set up during the first half of the 20th century and have been operating for more decades are still capable of educating people Christian, humanized, interactive, value- and personality-centred systems who are willing to actively participate in the public life and providing future teachers with a sense of professional call, self-esteem, worldand nation-concept, patriotism and justice along with a respect for themselves, for their fellow-beings and for God.

Keywords: Christian values, church mentality, church teacher training, Christian teacher, calling, our call, intrmediary art, original mentality and traditions 